\title{
Application on mobile platform "Idoso Ativo" (Active Aging): exercises for lower limbs combining technology and health
}

\author{
Aplicativo em plataforma móvel "Idoso Ativo": exercícios \\ para membros inferiores aliando tecnologia e saúde
}

Cláudia Márcia Ventura Teixeira Santos ${ }^{[a]}$, Janaína Alves de Andrade ${ }^{[a]}$, Alyne do Carmo Amorim ${ }^{[a]}$, Patricia Azevedo Garcia $^{[b]}$, Gustavo Azevedo Carvalho ${ }^{[a]}$, Karla Helena Coelho Vilaça ${ }^{[a]^{*}}$

[a] Universidade Católica de Brasília (UCB), Brasília, DF, Brazil

[b] Universidade de Brasília (UnB), Brasília, DF, Brazil

\section{Abstract}

Introduction: The introduction of a healthy lifestyle for the elderly from regular physical exercise is linked to physical independence and social wellness. The increasing integration of technology, including in the elderly's health area, extends an innovative and interactive approach towards the specific aspects of aging. Objective: To report the development of the application "Idoso Ativo" (Active Aging) with proposed exercises for the elderly population's lower limbs. Methods: The study belongs to the type 'original paper' which describes the development and accomplishment of the application for the health of the elderly. The study had the participation of an elderly model to perform exercises and video recording. The study was approved by the Research Ethics Committee of UCB and supported by CNPQ. Results: The Software development proposal involved interdisciplinary work for the selection of exercises for posture, balance and gait, development of the application and the use of a specific programming language with presentation of exercises on screens for easy understanding for

\footnotetext{
CMVTS: MS, e-mail: profclaudia.fisio@gmail.com JAA: BS, e-mail: janaina.alves.andrade@gmail.com ACA: BS, e-mail: alyneamorim36@gmail.com PAG: PhD, e-mail: patriciaagarcia@hotmail.com GAC: PhD, e-mail: carvalhobsb@hotmail.com KHCV: PhD, e-mail: kavilaca@yahoo.com.br
} 
the elderly public. Conclusion: The application developed can be adopted as a proposal in scientific studies in the physical therapy area and applied as an innovative resource combining health promotion and disease prevention.

Keywords: eHealth. Technology. Physical Therapy Specialty. Elderly.

\section{Resumo}

Introdução: A adoção do estilo de vida saudável pelo idoso a partir da prática de exercício físico regular está vinculada à independência física e ao bem-estar social. A crescente inserção da tecnologia, inclusive no âmbito da saúde do idoso, amplia de forma inovadora e interativa a abordagem perante os aspectos próprios do envelhecimento. Objetivo: Relatar a elaboração do aplicativo "Idoso Ativo" com proposta de exercícios para membros inferiores para a população idosa. Métodos: $O$ estudo é do tipo artigo original que descreve como foi o desenvolvimento e realização do aplicativo para a saúde do idoso. O estudo teve a participação de uma modelo idosa para realização dos exercícios e gravação em vídeo. O estudo teve aprovação do Comitê de Ética em Pesquisa da UCB e apoio do CNPQ. Resultados: A proposta de desenvolvimento do software envolveu, por meio de um trabalho interdisciplinar, a seleção de exercícios para postura, equilíbrio e marcha, elaboração do aplicativo, além da aplicação de uma linguagem de programação específica com apresentação de exercícios em telas de fácil compreensão para o público idoso. Conclusão: $O$ aplicativo desenvolvido pode ser adotado como proposta em estudos científicos na área da fisioterapia e ser aplicado como recurso inovador aliando promoção de saúde e prevenção de agravos.

Palavras-chave: e-Saúde. Tecnologia. Fisioterapia. Idoso.

\section{Introduction}

The health area has been going through great changes in the last couple of years, promoted by the recent technological advancements [1]. There has been fast increase in health intervention through the incorporation of mobile technology, which has been adopted for the increase in healthy behaviour and better life conditions for the populations [2].

The concept known as e-health refers to technologies applied to information and communication in the individual's and the populations' health care. One of the e-health components is the 'mobile health' (mHealth): this is the medicine or public health aided by the support of mobile devices, as cell phones, patient monitoring devices, digital personal assistants and other wireless devices. These are means which enable the transmission of different types of communication about health and wellness, through their applications [3 - 5].

The increasing growth rate of the elderly population has provoked the promotion of actions and resources that contribute to this group better quality of life and health, since aging represents a natural phase in the life cycle that presents biological effects associated to the decline of physiological, sensorial, cognitive and emotional functions, which have direct reflex on the elderly's interaction $[6,7]$.

In 2005, the World Health Organization (WHO) broadened the concept of "healthy aging" through the creation of the Elderly Health National Policy, which promotes not only the absence of organic diseases, but mainly, autonomy, independence and functional ability conditions. Seeking quality for the attention paid to old individuals, actions, policies and programs are developed, which are structured based on procedures of care focusing on the user, taking into consideration their rights, needs, preferences and abilities [8].

Therefore, it is relevant to encourage the elderly to keep a healthy lifestyle throughout aging, raising their awareness of the need to be physically active. Regular physical exercise and the adoption of an active lifestyle are means to promote their health, as a way to control non-transmittable chronic diseases that appear more frequently during aging and as a way to keep their functional independence [9].

In addition, several physical aspects can be improved by the use of technology, since proper 
means are offered that optimize the participation of old people in continuous physical activities, becoming important aids for the elderly's quality of life. Moreover, more and more old people have demonstrated good relationship with technology, and the technological insertion in the everyday life of this population has been observed as well [10].

Bearing that in mind, this paper aims at reporting the development of the application "Idoso Ativo" (Active Aging) for mobile devices (for the operational systems IOS and ANDROID) presenting proposals of functional exercises for the lower limbs for old people.

\section{Methods}

This study belongs to the type "experiment report" on the development of a mobile platform application called "Idoso Ativo" (Active Aging).

The study was approved by the Ethics and Research Committee of the Catholic University of Brasilia (n. 879.781/2014) and the application "Idoso Ativo" (Active Aging) was developed in three phases. For the app video recording, a woman over 70 years old was selected, who signed the Informed Consent form and the Use of Image Consent Form.

The project received financial support from CNPQ pursuant to the letter MCTI/CNPq N $14 / 2014$.
The research was carried out at the Catholic University of Brasilia, where the research team held their meetings and the app videos were recorded.

A team of technicians was hired for the graphic components and technological development, and they created the application interfaces within the criteria put forward by the researchers.

\section{Phase 1: Content Definition}

The choice of exercises included in the application was carried out after the survey of clinical tests and the formation of a panel of experts, who were two researcher physical therapists and two students in the physical therapy undergraduate course at the Catholic University of Brasilia. The physical exercises initially selected were those that evidenced significant results in the elderly's posture, balance and muscle strength.

After the main exercises had been selected from the survey of clinical tests, the committee discussed and chose the exercises that would be selected for videoing to be posted in the application. The exercises were divided into two phases according to the degree of difficulty and presented in four types: warm-up, strength, balance and relaxation. Table 1 presents each exercise with the description of how to do them.

Table 1 - Exercises selected after survey of clinical tests

\begin{tabular}{|c|c|c|c|}
\hline Phases & Variations/Types & Exercise & Exercise description \\
\hline Phase 1 & Warm-up & Gait without dislocation & $\begin{array}{l}\text { Start this exercise, simulating a walk without dislocation. Do this exercise for } \\
2 \text { minutes. Do it more slowly in the first minute and in the following minute, } \\
\text { intensify the pace. }\end{array}$ \\
\hline Phase 1 & Warm-up & $\begin{array}{l}\text { Gait without dislocation } \\
\text { with LL suspension. }\end{array}$ & $\begin{array}{l}\text { Remain in the same place, keep on simulating the walk, bending the knees a } \\
\text { little more. Do this exercise at a faster pace for } 2 \text { minutes. }\end{array}$ \\
\hline Phase 1 & Warm-up & $\begin{array}{l}\text { Flexion and extension } \\
\text { of the trunk raising a } \\
\text { ball. }\end{array}$ & $\begin{array}{l}\text { Place the ball on the floor in front of you, grab the ball bending the column } \\
\text { forwards and stretch your arms lifting the ball until it is over your head. Do } \\
\text { this exercise for } 1 \text { minute. }\end{array}$ \\
\hline Phase 1 & Strength & LL Abduction. & $\begin{array}{l}\text { Lean on the back of a chair and raise the leg sideways. Keep a straight } \\
\text { posture. Do } 3 \text { series of } 12 \text { repetitions for each side. }\end{array}$ \\
\hline Phase 1 & Strength & Thigh back. & $\begin{array}{l}\text { Lean on the back of a chair and bend the leg contracting the back of your } \\
\text { thigh. Do } 3 \text { series of } 12 \text { repetitions for each side. }\end{array}$ \\
\hline Phase 1 & Strength & Mini squat & $\begin{array}{l}\text { Open your legs so that your feet are aligned to your shoulders. Put your hands } \\
\text { on your waist. Squat as if you are going to sit on a chair, in a mini-squat. Do } 3 \\
\text { series of } 12 \text { repetitions. }\end{array}$ \\
\hline Phase 1 & Balance & Bending with a stick & $\begin{array}{l}\text { Stand up supported by the stick, give one step backwards bending the knees } \\
\text { without touching the floor. Do the movement up and down. Do } 3 \text { series of } 12 \\
\text { repetitions changing the sides. }\end{array}$ \\
\hline
\end{tabular}

(To be continued) 
Table 1 - Exercises selected after survey of clinical tests

\begin{tabular}{|c|c|c|c|}
\hline Phases & Variations/Types & Exercise & Exercise description \\
\hline Phase 1 & Balance & Balance on one foot & $\begin{array}{l}\text { Raise the arms sideways along with one of the legs backways. Bend your } \\
\text { trunk forward. Keep the position for } 5 \text { seconds. Do this exercise } 3 \text { times for } \\
\text { each side. }\end{array}$ \\
\hline Phase 1 & Balance & LL Flexion & $\begin{array}{l}\text { Stand next to a chair, if necessary hold the back of the chair with one of your } \\
\text { hands. If not necessary, keep your hands on your waist. Bend your knees and hip } \\
\text { moving the knee towards your head. Do } 3 \text { series of } 12 \text { repetitions for each side. }\end{array}$ \\
\hline Phase 1 & Relaxation & Cervical stretching & $\begin{array}{l}\text { Bend your head slightly to the left, use your hand to help the movement and } \\
\text { stretch your neck for } 20 \text { seconds. Repeat to the other side. Do the same } \\
\text { process stretching backwards and forwards. }\end{array}$ \\
\hline Phase 1 & Relaxation & Stretching of addutors & $\begin{array}{l}\text { Sit in a chair and cross your legs. With your hands pull the leg that is on the } \\
\text { top closer to your abdomen. Hold it for } 20 \text { seconds. Do the same movement } \\
\text { with the other leg. }\end{array}$ \\
\hline Phase 1 & Relaxation & $\begin{array}{l}\text { Stretching the back of } \\
\text { your leg. }\end{array}$ & $\begin{array}{l}\text { Sit in a chair and stretch one leg with the foot pointing upwards, bend your } \\
\text { trunk towards the foot. Keep this movement for } 20 \text { seconds. Do the same } \\
\text { movement with the other side. }\end{array}$ \\
\hline Phase 2 & Warm-up & Gait with obstacles & $\begin{array}{l}\text { Walk forwards overcoming the obstacles in a straight line, go back doing the } \\
\text { same movement. Walk sideways overcoming the obstacles. Do } 2 \text { series of } \\
\text { each exercise. }\end{array}$ \\
\hline Phase 2 & Warm-up & Step & $\begin{array}{l}\text { Bend hip and knees and go up a step using one foot and then the other. Do it } \\
\text { alternating the feet. Do the movement for } 2 \text { minutes. }\end{array}$ \\
\hline Phase 2 & Warm-up & Star jump & $\begin{array}{l}\text { Open your arms above your head, and at the same time open your legs } \\
\text { quickly. Do this movement } 12 \text { times non-stop. }\end{array}$ \\
\hline Phase 2 & Strength & $\begin{array}{l}\text { LL extension with a } \\
\text { chair }\end{array}$ & $\begin{array}{l}\text { Sit in a chair and keep your column straight, stretch your leg and bend the hip. } \\
\text { Do } 3 \text { series with } 12 \text { repetitions for each side. }\end{array}$ \\
\hline Phase 2 & Strength & $\begin{array}{l}\text { Back of the leg with } \\
\text { gait on the tip of your } \\
\text { toes }\end{array}$ & $\begin{array}{l}\text { Lean against the back of the chair and move as if projecting your body } \\
\text { upwards, sustaining it by contracting the muscles of the back of your leg. Do } \\
3 \text { series of } 12 \text { repetitions. Leave the chair and walk on the tip of your toes. Do } \\
3 \text { series of } 10 \text { steps. }\end{array}$ \\
\hline Phase 2 & Strenth & $\begin{array}{l}\text { Bending with body } \\
\text { suspension. }\end{array}$ & $\begin{array}{l}\text { Sit in a chair, raise your body with the help of your arms holding the seat } \\
\text { and bend your legs until you are close to the floor, then return to the sitting } \\
\text { position. Do } 3 \text { series of } 12 \text { repetitions. }\end{array}$ \\
\hline Phase 2 & Balance & Transferring dumbbell. & $\begin{array}{l}\text { Stand up, with your legs apart bend your trunk and do the movement of passing } \\
\text { the dumbbell between the legs, starting the movement with the dumbbell entering } \\
\text { between the legs and leaving on the lateral. Do } 3 \text { series of } 12 \text { repetitions }\end{array}$ \\
\hline Phase 2 & Balance & $\begin{array}{l}\text { Suspending an object } \\
\text { on the lateral. }\end{array}$ & $\begin{array}{l}\text { Put your feet apart, stretch your arms above your head holding a ball. Bend } \\
\text { the legs and trunk and move the ball to one side towards the floor. Go back to } \\
\text { the initial position standing up and bend your body again taking the ball to the } \\
\text { other side. Do } 3 \text { series of } 12 \text { repetitions. }\end{array}$ \\
\hline Phase 2 & Balance & Bending with dumbbell & $\begin{array}{l}\text { Move your right foot a step forward, bend the left knee without touching the } \\
\text { floor. Do the exercise alternating the feet } 4 \text { times. Do } 3 \text { series. To make the } \\
\text { exercise a little harder you can use a dumbbell in each hand. }\end{array}$ \\
\hline Phase 2 & Relaxation & Quadriceps stretching. & $\begin{array}{l}\text { Stand up behind a chair and hold the back of the chair with one hand and your } \\
\text { foot with the other hand. Wait } 20 \text { seconds and repeat to the other side. Keep } \\
\text { your column straight during the exercise. }\end{array}$ \\
\hline Phase 2 & Relaxation & $\begin{array}{l}\text { Stretching the back of } \\
\text { your leg. }\end{array}$ & $\begin{array}{l}\text { Stand up behind a chair, hold the back of the chair with both your hands, move } \\
\text { a step backwards and stretch the leg that is behind flexing the leg that is in front. } \\
\text { Keep the movement for } 20 \text { seconds and do the same with the other side. }\end{array}$ \\
\hline Phase 2 & Relaxation & Global stretching. & $\begin{array}{l}\text { Stand up, keep your column straight and breathe deeply. Stand on the tip of } \\
\text { your toes, raise your arms above the head and count to } 5 \text {, then release the air } \\
\text { and go back to the initial position. Do } 4 \text { series of } 5 \text { seconds. }\end{array}$ \\
\hline Walking & & Moderate walk & $\begin{array}{l}\text { Go walking in a moderate pace every other day, alternating with the exercises, } \\
\text { either in open air or in a proper place. Walking is a low impact physical } \\
\text { exercise which increases vitality. Keep shoulders and arms relaxed and a } \\
\text { constant pace. Heart beat must be kept at a stable rhythm. }\end{array}$ \\
\hline
\end{tabular}


Phase 2: Sampling and video recording

Meetings were held every other week to discuss the project and organize the data.

An elderly was selected to record the video, the participant was over 70 years old, functionally independent and cognitively able to understand the exercises proposed. She signed an informed consent form and an image rights form to take part in the research.

The video recording was carried out in three sessions. The video images were produced by a professional team aided by the team of physical therapists. The whole team was concerned to present a lit environment, free of noises, with suitable lighting both for the technical effects and the safety of the participant. The audio for the exercises was recorded simultaneously with the clear description of how to perform them.

Mechanotherapy equipment was used to perform some of the exercises, such as sticks, dumbbells, steps, ball and chair. The interdisciplinary work of the professionals was important during the video recording aiming at the suitable performance of the exercises and the sound and image quality. It seems important to emphasize the need of previous training with the elderly participant for better execution of the exercises proposed, arrangement of the equipment and team synchrony.

The videos were edited by the communication team using the Adobe premier editor and after being approved by the team of physical therapists, it was sent to the programmers who were responsible for the design of the application layout.

\section{Phase 3: Application programming}

A plan was devised including how the application would be developed, the functionalities to be made available to the users, the interface to be used as well as the safety elements related to data storage and content presentation. Therefore, it was necessary to count on professionals of the information technology area to develop the application and make it available in digital media, with the purpose of designing it in an interactive and user friendly manner.

\section{Results and discussion}

The software was produced by a team of computing technicians who were experienced in the application programming area. A framework called PhoneGap was used, whose choice was based on promoting interoperability between the main mobile operational systems currently available. This implies that, for the developer, the application can be designed using a single source-code, which is processed and compiled in different programming languages, according to each mobile operational system. The devices considered mobile systems are digital personal assistant, cell phone, tablet or smart phone, characterized by their processing power, local storage, access to data transmission technology such as Wireless Fidelity (Wifi) and Bluetooth, equipped with an operational system adapted to their hardware specifications [11]. Also, the application was made available to mobile devices, tablet, cell phone and smart phones with free access developed for the systems IOS, Android and Windows Phone.

The window as well as the whole application layout went through a process of choice of colors, fonts, sizes and graphic design proposed by the developer, revised by the team with tests and returned for the necessary changes until the desired application was obtained.

The application shows an initial screen with presentation and objectives to be achieved, the brand of the proponent institution and the logo of the study financial support agency (Figure 1). It also presents the tutorial with instructions for the user and the way to navigate to other windows, a screen with instructions and recommendations for the performance of the exercises proposed as well as a screen with a form for the register of the elderly containing name, age, weight, height, sex and email address.

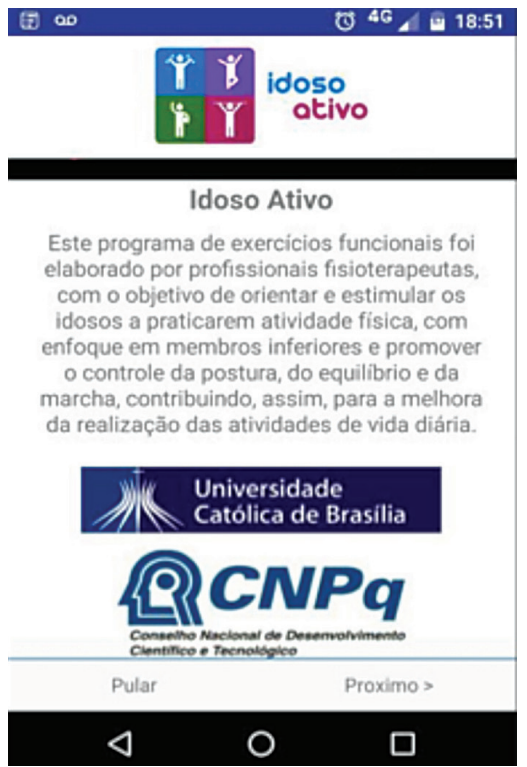

Figure 1- Initial screen with the application presentation. 
The following screens illustrate the phases (Figure 2) and their modalities, enabling the elderly to customize their training program and follow the performance of the exercises (Figure 3) with the availability of explaining videos for each exercise. Each phase was divided into four modalities which are: warm-up, strength, balance and relaxation, with three exercises each.

At the beginning of each phase, a preview of the exercises that were used was added with explanations about the phase and instructions of use (Figure 4).

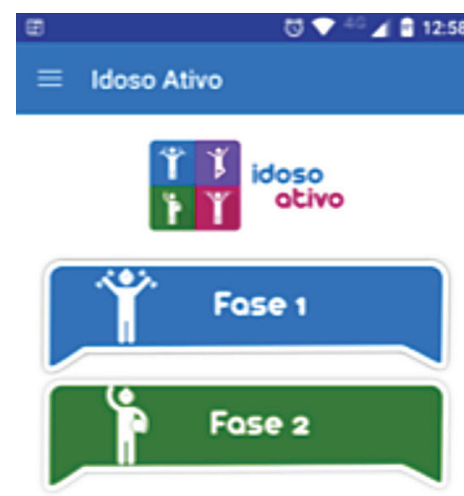

$\triangleleft$

\section{O}

口

Figure 2 - Presentation for phase selection.

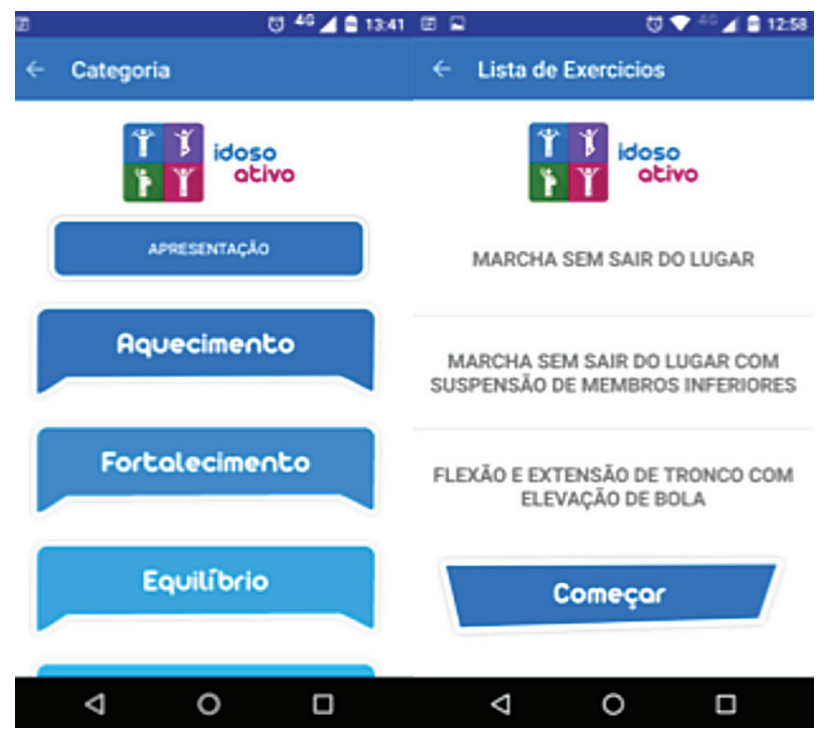

Figure 3 - Presentation for the selection of modalities and exercises.
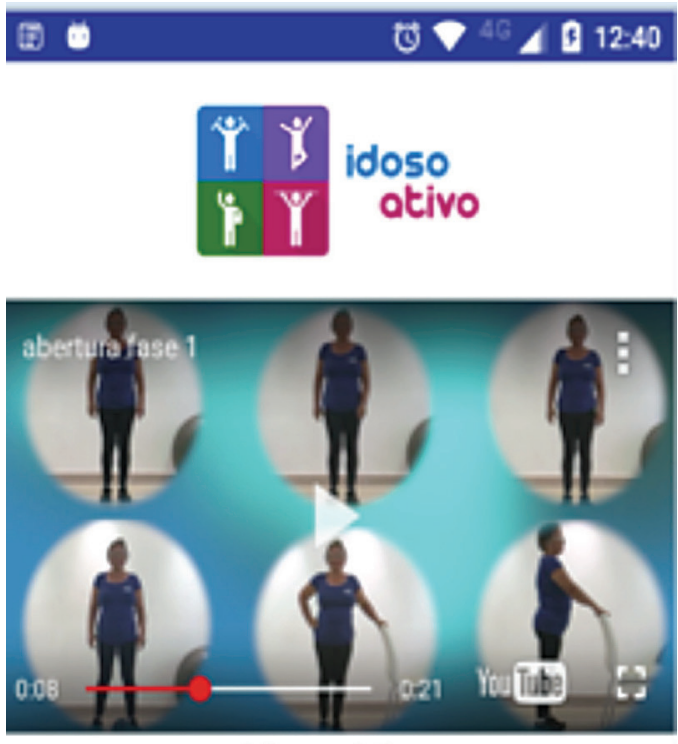

Idoso Ativo

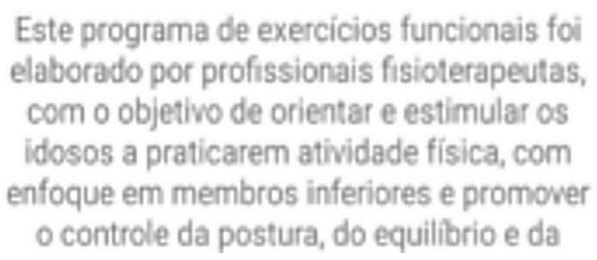

Figure 4 - Preview with presentation of each phase.

The application also presents a menu in the lateral tab, which makes it possible to access instructions, register change and user change, enabling the register of more than one old person in the same device.

When each modality of exercises is finished, the user is directed to reply in a window that opens the Borg scale [12], from the icon "finalizei o exercício" (exercise ended), according to its perceived exertion, and the results are sent to the MySQL data base hosted in the online server REST Json available for the professional that needs to have access to this information, following the old person's performance along the training.

The application "Idoso Ativo" (Active Aging) was officially registered by the proponent institution along with the researchers.

\section{Technology allied to health}

Physical activity developed by the elderly characterizes the adoption of an active lifestyle, indispensable to be healthy, since physical abilities are developed, which have been sometimes limited 
by the aging process [13]. Reduction in the physical activity levels appears as a risk factor related to the development and worsening of chronic diseases such as obesity, diabetes and circulatory system illnesses, with the need to implement programs promoting physical activities [14].

The relation between physical activity, health, quality of life and aging seems to be evident, and has been more and more discussed and scientifically investigated. This has resulted in a consensus that physical exercise is a determining factor for the functional improvement of these individuals [13]. For the elderly, functional exercises are beneficial to maintain and improve their strength and muscle power, which are necessary to keep them independent in their daily life activities [15]. Flexibility, agility, strength, balance, aerobic resistance and psychosocial aspects provide the elderly with a holistic approach to quality of life and the elderly need this interaction both in their families and in the society as a whole [16].

The proposal for the selection of exercises in the application considered aspects such as frequency, intensity, number of repetitions and also the progression for their execution, aiming at the elderly's physical and functional performance. It is relevant to highlight that the selection of exercises must include functional exercises, suitable for increasing physical performance and that promote the improvement of strength, balance and posture, therefore, developing these individuals' functional capability as a whole [17]. Another very important aspect regards suitable recommendations and instructions for the exercises proposed, so that their wrong execution or beyond the maximum capability presented by the individual is prevented. It seems also important to consider an appointment with a qualified professional that will follow the training, being aware of the elderly's needs and possible complications, so that the training program can be safely carried out [18].

The literature presents reports on the adoption of technologies as useful and interactive media able to promote health. A study developed in the United States identified software and applications related to healthy eating habits, physical activity, personal health and wellness [19].

Many studies have already demonstrated that the development and use of applications have helped treatments and diagnosis, in specific cases, have broadened the health approach and become beneficial due to the prevention and control of illnesses such as diabetes $[4,20]$. A study has also been reported using the technology developed for the control and monitoring of glucose levels in young patients with diabetes type 1 , whose project included bands to measure the glucose levels and were available in mobile applications, present in iPhone or iPod Touch and a glucometer with a Bluetooth adaptor to transfer the information about the glucose levels in the blood automatically to the application [20].

The approach to health has already included elderly groups in research using the technology of applications, specifically to improve cognitive capability. In a study by Hartin et al. [21], for example, to help old people with dementia, a reminder application was created for smartphones as an instrument to collect data and register important information, and that when used resulted in the improvement of the recognition of the registers by the elderly. While a study by Pestili and Betti [22] developed the application "Remember", used with the purpose of postpone the loss of cognitive functions in old people with Alzheimer.

Regarding weakness, Santos et al. [23] developed an application in platform android, able to identify quickly and safely the characteristics of fragility syndrome in old people, configuring the application as a prevention strategy, since the early detection of fragility is very important for the treatment. Rodriguéz et al. [24] used this technology to monitor physical activity allied with healthy habits on an everyday basis, confirming that new technologies are useful to promote healthier lifestyles and that their effects are beneficial in relation to arterial aging.

As regards experiment reports or scientific papers describing the use of applications to perform functional exercises in the elderly, there are not many, despite the stage of development of the technological resources used in the health area [25]. This might be explained by the fact that this is something relatively new in the scientific and research areas. Therefore, considering this information, this study might be seen as an innovation for the aging and for the physical therapy areas of interest, since its proposal includes the access to technology through the applications, which has not been mastered by most of the elderly, and leads to health through functional exercises. 
For the steps of construction of a health application, which in this study comprised a series of exercises to develop the functional capability of old people, it is important to consider that there was correlation between the theoretical background and the selection of content for this project. The content was made available by the team of physical therapists while the definition of programming phases using technological concepts was carried out by the team designing the project. Therefore, the importance of interdisciplinarity among the professionals of communication and design, the programming team and the physical therapists for the final quality of the work was confirmed.

The structure of an application requires knowledge about its users, taking into consideration the accessibility that comprises understandable vocabulary, content that is easy to be read and clear audio instructions. In this sense, it is necessary that the team takes into consideration the users' needs, since many times old people have difficulties to deal with new technologies, due to the fast evolution of devices. Therefore, new technologies might be seen as a barrier to their use, generating the sensation of exclusion and lack of skills, limiting the interaction between the old person and the interactive system [26, 27].

One example of the importance of being aware of the users of an application is the study by Blackman et al. [28], where the participants were adolescents, the technology was made available to smartphones through competitive games that led to physical activity, that is, competitiveness, which is common in this age range, was used to make the application more appealing to its users.

Taking into consideration the several advances in technologies, including the use of applications, it becomes clear how relevant they are in the social change process, since they promote the appearance of a new society where technological resources are part of the everyday life of most individuals, including the elderly, providing them with great advance in relation to the health area, promoting resources that can be used to prevent and treat comorbidities common to the aging process. A study by Lolli et al. [29] reported that the elderly tend to consider the interaction with technology significant for their insertion in the society, in addition to making their daily activities easier.
In relation to limitations, we might consider that for being a field in expansion in the physical therapy area, there were difficulties of communication between the team of physical therapists and the information technology professionals. Specific knowledge in both areas was needed for the programming of phases and tabs that appeared in the application, aiming at offering to the final user, a user friendly technology, enjoyable navigation and that could meet the needs inherent in the aging process. Liao et al. [30] presented a study that analyzed the users' perception when questioning whether the needs matched the current functions offered in applications, highlighting that the efficacy of the application, allied to the activities proposed and design were the features that called the users' attention.

Another limitation to the use might be the high cost to develop studies like these. Fortunately, this study was financially supported by CNPq, which granted funds for the research, but it is necessary to understand that more investment from the public and private sectors are vital to promote advances in the health technology area.

The development of the application "Idoso Ativo" (Active Aging) aims at providing the elderly with one more option of planned physical exercises. Due to the increasing search for a healthier lifestyle, with the perspective of more independent movements, the approach proposed is to ally this habit to the new technological support.

\section{Conclusion}

The development of an application despite being inserted in the health context, represents something new when associated to the proposal of functional exercises destined to old people, and it seems to be more and more important to develop projects that promote the relation between the use of technology and physical activity in the aging process.

The application designed and presented contributes to the development of important future scientific studies seeking to evidence its efficacy and usability as well as its content, besides presenting an innovative resource allied to the promotion of old people's health. 


\section{References}

1. Barra DCC, Nascimento ERP, Martins JJ, Albuquerque GL, Erdmann AL. Evolução histórica e impacto da tecnologia na área da saúde e da enfermagem. Rev Eletronica Enferm. 2006;8(3):422-30.

2. Free C, Phillips G, Galli L, Watson L, Felix L, Edwards $\mathrm{P}$, et al. The effectiveness of mobile-health technology-based health behaviour change or disease management interventions for health care consumers: a systematic review. PLoS Med. 2013;10(1):e1001362.

3. Ariza LLC, Ospino MJR, Delgado BM. Servicio de mHealth para supervisar medidas corporales de glucosa y tensión arterial. EAC. 2014;35(2):62-72.

4. Valentiner LS, Ried-Larsen M, Karstoft K, Brinkløv CF, Brøns C, Nielsen RO, et al. Long-term effect of smartphone-delivered Interval Walking Training on physical activity in patients with type 2 diabetes: protocol for a parallel group single-blinded randomised controlled trial. BMJ Open. 2017;7(4):e014036.

5. Kruse CS, Krowski N, Rodriguez B, Tran L, Vela J, Brooks M. Telehealth and patient satisfaction: a systematic review and narrative analysis. BMJ Open. 2017;7(8):e016242.

6. Czaja SJ, Lee CC. The impact of aging on access to technology. Univ Access Inf Soc. 2007;5:341-9.

7. Rasche P, Mertens A, Bröhl C, Theis S, Seinsch T, Wille M, et al. The "Aachen fall prevention App" - a Smartphone application app for the self-assessment of elderly patients at risk for ground level falls. Patient Saf Surg. 2017;11:14.

8. Brasil. Ministério da Saúde. Portaria nº 2.528, de 19 de outubro de 2006. Aprova a Política Nacional de Saúde da Pessoa Idosa. Diário Oficial da União. 1999 dez 13; Seção 1. p. 20.

9. Litman L, Rosen Z, Spierer D, Weinberger-Litman S, Goldschein A, Robinson J. Mobile exercise Apps and Increased Leisure Time Exercise Activity: A Moderated Mediation Analysis of the Role of Self-Efficacy and Barriers. J Med Internet Res. 2015;17(8):e195.

10. King AC, Hekler EB, Grieco LA, Winter SJ, Sheats JL, et al. Harnessing Different Motivational Frames via Mobile Phones to Promote Daily Physical Activity and Reduce Sedentary Behavior in Aging Adults. PLOS ONE. 2013;8(4): e62613.
11. Oliveira TR, Costa FMR. Desenvolvimento de aplicativo móvel de referência sobre vacinação no Brasil. J Health Inform. 2012;4(1):23-7.

12. Brunetto AF, Paulin E, Yamaguti WPS. Comparação entre a escala de Borg modificada e a escala de Borg modificada análogo visual aplicadas em pacientes com dispnéia. Rev Bras Fisioter. 2002;6(1):41-5.

13. Matsudo SM, Matsudo VKR, Barros Neto TL. Atividade física e envelhecimento: aspectos epidemiológicos. Rev Bras Med Esporte. 2001;7(1):2-13.

14. Ribeiro RM, Tribess SS, Santos AS, Pinto LLT, Ribeiro MCL, Roza LB, et al. Barriers to the involvement of the elderly in public services to promote physical activity. Cien Saude Colet. 2015;20(3):739-49.

15. Lustosa LP, Oliveira LA, Santos LS, Guedes RC, Parentoni AN, Pereira LSM. Efeito de um programa de treinamento funcional no equilíbrio postural de idosas da comunidade. Fisioter Pesqui. 2010;17(2):153-6.

16. Pereira AMG, Paulo TRS, Santos SFS. Efeito do exercício físico na capacidade funcional e atividade da vida diária em idosos: revisão sistemática. Acta Bras Mov Hum. 2015;5(2):79-95.

17. Leal SMO, Borges EGS, Fonseca MA, Alves Jr ED, Cader S, Dantas EHM. Efeitos do treinamento funcional na autonomia funcional, equilíbrio e qualidade de vida de idosas. R Bras Ci e Mov. 2009;17(3):61-9.

18. Fernandes AMBL, Ferreira JJA, Stolt LROG, Brito GEG, Clementino ACCR, Sousa NM. Efeitos da prática de exercício físico sobre o desempenho da marcha e da mobilidade funcional em idosos. Fisioter Mov. 2012;25(4):821-30.

19. West JH, Hall PC, Hanson CL, Barnes MD, GiraudCarrier C, Barrett J. There's an app for that: content analysis of paid health and fitness apps. J Med Internet Res. 2012;14(3):e72.

20. Cafazzo JA, Casselman M, Hamming N, Katzman DK, Palmert MR. Design of an mHealth app for the selfmanagement of adolescent type 1 diabetes: a pilot study. J Med Internet Res. 2012;14(3):e70.

21. Hartin PJ, Nugent CD, McClean SI, Cleland I, Norton MC, Sanders C, et al. A smartphone application to evaluate technology adoption and usage in persons with dementia. Conf Proc IEEE Eng Med Biol Soc. 2014;2014:5389-92. 
22. Pestili LC, Betti NFS. Remember - Aplicativo para o auxílio de idosos com Alzheimer. XIII CEEL Conferência de Estudos em Engenharia Elétrica; 2015 Oct 12-16; Uberlândia, MG. Uberlândia: Universidade Federal de Uberlândia; 2015. Available from: https:// tinyurl.com/yalhyxmw.

23. Santos TS, Brito TA, Yokoyama Filho, Guimarães LA, Souto CS, Souza SJN, et al. Desenvolvimento de aplicativo para dispositivos móveis voltado para identificação do fenótipo de fragilidade em idosos. Rev Bras Geriatr Gerontol. 2017;20(1):67-73.

24. Recio-Rodríguez JI, Martín-Cantera C, GonzálezViejo N, Gómez-Arranz A, Arietaleanizbeascoa MS, Schmolling-Guinovart $Y$, et at. Effectiveness of a smartphone application for improving healthy lifestyles, a randomized clinical trial (EVIDENT II): study protocol. BMC Public Health. 2014;14:254.

25. Lopes ALM, Silva SA, Castro DFA, Bógus CM, Fracolli LA. Avaliação de programas, serviços e tecnologias na perspectiva da promoção da saúde: uma reflexão teórica. Rev Bras Promoc Saude. 2013;26(4):590-4.

26. Fischer SH, David D, Crotty BH, Dierks M, Safran C. Acceptance and use of health information technology by community-dwelling elders. Int J Med Inform. 2014;83(9):624-35.
27. Souza CM, Silva AN. Aplicativos para smartphones e sua colaboração na capacidade funcional de idosos. Re Saud Digi Tec Edu. 2016;1(1):6-19.

28. Blackman KCA, Zoellner J, McCrickard DS, Harlow J, Winchester WW, Hill JL, et al. Developing mobile apps for physical activity in low socioeconomic status youth. J Mob Technol Med. 2016;5(1):33-44.

29. Lolli MCGS, Maio ER. Uso de tecnologia por idosos: Perfil, motivações, interesses e dificuldades. Rev Educ Cult Soc. 2015;5(2):211-23.

30. Liao GY, Chien YT, Chen YJ, Hsiung HF, Chen $\mathrm{HJ}$, Hsieh $\mathrm{MH}$, et al. What to Build for MiddleAgers to Come? Attractive and Necessary functions of Exercise-Promotion Mobile Phone Apps: A Cross-Sectional Study. JMIR Mhealth UHealth. 2017;5(5):e65.

Received in 09/17/2017

Recebido em 17/09/2017

Approved in 10/16/2017

Aprovado em 16/10/2017 